\title{
Komentarz. Plejotropizm - co to znaczy i czy termin ten odnosi się również do riwaroksabanu?
}

\author{
The commentary. Pleiotropic - what does it mean and does this term \\ also apply to rivaroxaban?
}

prof. dr hab. n. med. Krzysztof J. Filipiak

I Katedra i Klinika Kardiologii Warszawskiego Uniwersytetu Medycznego

\section{PLEJOTROPIZM — DEFINICJA}

Plejotropizm to termin dziś już powszechnie zadomowiony w farmakologii klinicznej, chociaż de facto wywodzi się z genetyki. Plejotropia (z języka greckiego: $\pi \lambda \varepsilon \iota \varpi v$ [pleion] — więcej, $\tau$ ролоб [tropos] — sposób, metoda; nota bene - w piśmiennictwie pojawia się również zapis z języka greckiego z literą „1" - „pleios", ponieważ część osób razi spolszczanie tego wyrazu do form ' plejotropowy', 'plejotropizm') jest zjawiskiem, w którym pojedynczy czynnik wpływa na dwie lub więcej odrębnych, często pozornie niepowiązanych ze sobą cech fenotypowych — dlatego genetycy zaczęli mówić o "genie plejotropowym" wpływającym na różne fenotypy, a farmakolodzy kliniczni przenieśli to na definicję „leku plejotropowego", czyli takiego, który ma wiele mechanizmów działania, zwłaszcza tych opisanych poza pierwszym, kanonicznym mechanizmem farmakologicznym.

Tym pierwszym mechanizmem kanonicznym może być na przykład działanie hipolipemizujące statyn, a wszystkie inne działania tych leków (działania pozahipolipemizujące) określane będą mianem mechanizmu plejotropowego. Podobnie tikagrelor to lek przeciwpłytkowy o głównym mecha- nizmie działania związanym z receptorami $\mathrm{P}_{2} \mathrm{Y}_{12}$, natomiast jego działania plejotropowe powiązano z układem adenozynowym. Coraz częściej mówi się o plejotropowych działaniach leku antyhiperglikemicznego - metforminy, która na przykład obniża ryzyko niektórych nowotworów. Czy w tych przykładach również mieści się riwaroksaban ? Czy poza znanym mechanizmem wpływu na kaskadę krzepnięcia (mechanizm związany z antagonizowaniem czynnika Xa) lek ten wykazuje inne, plejotropowe działania?

\section{RIWAROKSABAN — DLACZEGO MÓWIMY O PLEJOTROPOWOŚCI TEGO LEKU?}

Dyskusja i poszukiwania plejotropowych mechanizmów działania riwaroksabanu toczą się od dawna, a rozpoczęly się już po wynikach badania ATLAS ACS2 TIMI 51 (Anti-Xa Therapy to Lower Cardiovascular Events in Addition to Standard Therapy in Subjects with Acute Coronary Syndrome-Thrombolysis in Myocardial Infarction 51), w którym dodatnie małych dawek riwaroksabanu $(2 \times 2,5 \mathrm{mg})$ do rutynowego leczenia dwoma lekami przeciwpłytkowymi (kwas acetylosalicylowy [ASA, acetylsalicylic acid] i klopidgrel) 


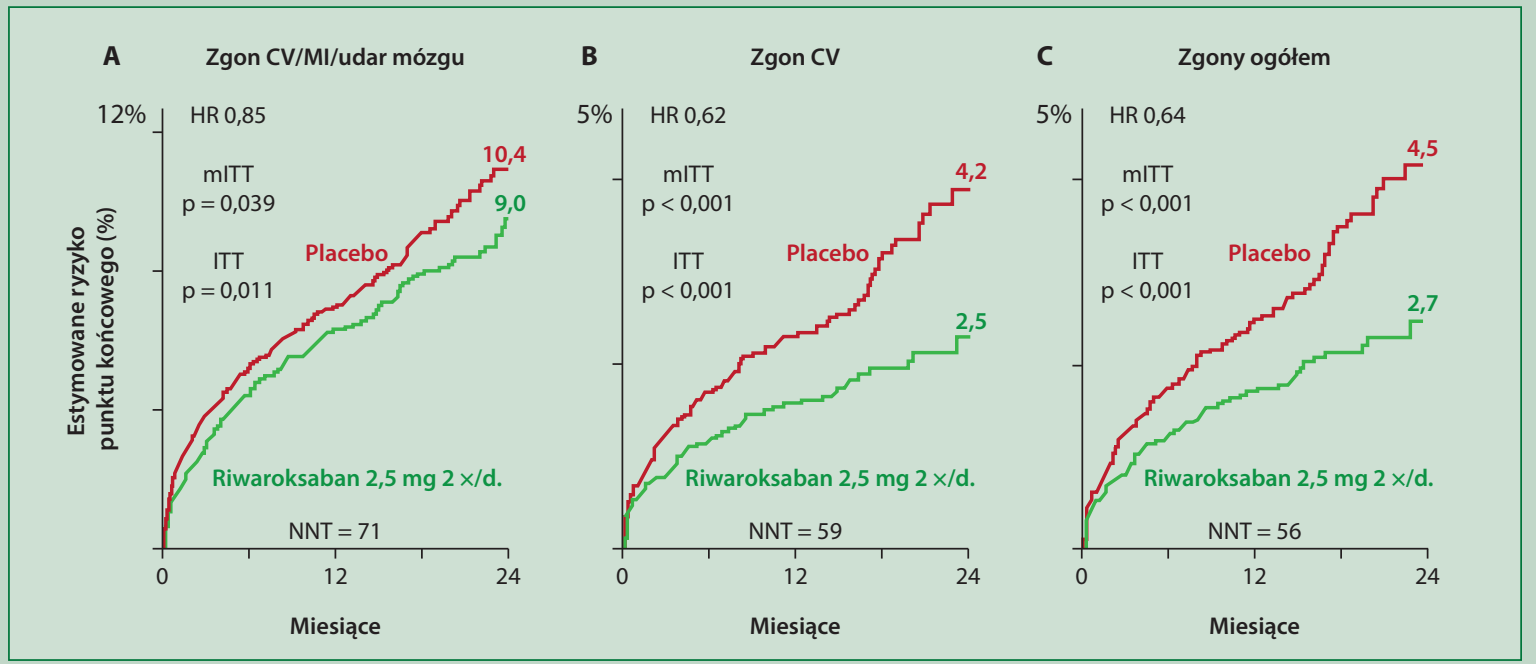

Rycina 1A-C. Wyniki badania ATLAS ACS-2 TIMI 51. Wykresy rozejścia się krzywych ilustrują paradoksalnie większy wpływ dodania małych dawek riwaroksabanu na śmiertelność całkowitą niż na śmiertelność sercowo-naczyniową (CV, cardiovascular), a tym bardziej na główny punkt końcowy (zgon, zawał serca [MI, myocardial infarction], udar mózgu); HR (hazard ratio) — ryzyko względne; ITT (intention needed-to-treat) — istotność statystyczna dla analizy wg intencji leczenia (randomizacji); mITT (modified intent-to-treat analysis) zmodyfikowana analiza wg intencji leczenia; NNT (number needed-to-treat) — liczba osób, którą trzeba leczyć, aby uniknąć jednego zdarzenia

przynosiło wymierne korzyści kliniczne w stosunku do grupy poddanej przez 2 lata terapii według schematu ASA + klopidogrel + placebo. Gdyby dodanie riwaroksabanu do dwóch leków przeciwpłytkowych miało potencjalizować ich działanie, to powinniśmy widzieć to przede wszystkim w obniżaniu ryzyka zawału serca i udaru mózgu. Tymczasem, dość nieoczekiwanie, dodanie małych dawek riwaroksabnu przekładało się przede wszystkim na zmniejszenie ryzyka zgonów sercowo-naczyniowych oraz zgonów z dowolnej przyczyny (śmiertelność całkowita). To dość nieoczekiwane zjawisko przypomniano na rycinie 1 .

\section{PLEJOTROPOWOŚĆ RIWAROKSABNU}

Ta wyjątkowość działania małych dawek riwaroksabnu ma już swoją ugruntowaną literaturę, przedstawioną szczegółowo w komentowanym artykule dr Anny Płatek i doc. Filipa M. Szymańskiego. Obecnie wiadomo, że zahamowanie przez riwaroksaban specyficznych receptorów aktywowanych przez proteazy typu 1 (PAR-1, protease-activated receptors 1) i typu 2 (PAR-2) wpływa na wiele komórek poza płytkami krwi oraz hamuje wiele procesów prowadzących do miażdżycy. Riwaroksaban oddziałuje nie tylko na receptory PAR-1 (podobnie jak bezpośredni inhibitor trombiny - dabigatran), ale również na receptory PAR-2, wpływając w ten sposób także na ograniczenie miejscowego stanu zapalnego, zmniejsza migrację leukocytów przez śródbłonek, redukuje angiogenezę oraz zmniejsza objętość blaszki miażdżycowej, co bezpośrednio przekłada się na jego działanie przeciwzapalne i przeciwmiażdżycowe.

W ostatnim czasie eksperci odpowiednich sekcji Polskiego Towarzystwa Kardiologicznego przygotowali ważne stanowiska dotyczące riwaroksabnu, jego plejotropowości, a także w kontekście tej plejotropowości - miejsca badania COMPASS w określeniu nowych zasad stosowania tak zwanych naczyniowych, małych dawek tego leku, a więc stosowania riwaroksabnu w miażdżycy naczyń, $\mathrm{w}$ dawce 2 razy 2,5 mg/dobę [1,2]. W dokumentach tych przeczytamy między innymi ważne informacje dotyczące debaty, jaka toczy się nad plejotropowością riwaroksabanu, w której próbujemy odpowiedzieć jak wytłumaczyć plejotropowe działanie tego leku i czy ważniejsze jest oddziaływania na receptory PAR-2, czy też przeciwzakrzepowe działanie ksabanów - nawet $\mathrm{w}$ bardzo małych dawkach. Z dokumentów tych czytelnik dowie się, że o ile hipoteza hamowania aktywności PAR-2 oparta jest na modelach doświadczalnych w warunkach in vitro, o tyle analiza innych badań 
Tabela 1. Porównanie wyników badania PEGASUS z wynikami badania COMPASS — dwa plejotropowe podejścia do optymalizacji leczenia przeciwpłytkowego w modelu pacjentów z miażdżycą

\begin{tabular}{|l|c|c|}
\hline Porównywany punkt końcowy & $\begin{array}{c}\text { Badanie PEGASUS } \\
\text { (tikagrelor 60 mg + ASA) }\end{array}$ & $\begin{array}{c}\text { Badanie COMPASS } \\
\text { (riwaroksaban 2 } \times 2,5 \text { mg + ASA) }\end{array}$ \\
\hline Pierwszorzędowy punkt końcowy & Obniżenie o 16\% & Ograniczenie o 24\% \\
\hline Zgon sercowo-naczyniowy & Obniżenie o 17\% (NS) & Obniżenie o 22\% \\
\hline Zgon z dowolnej przyczyny & Obniżenie o 11\% (NS) & Obniżenie o 18\% \\
\hline Zawał serca & Obniżenie o 16\% & Obniżenie o 14\% (NS) \\
\hline Udar mózgu & Obniżenie o 25\% & Obniżenie o 42\% o 39\% \\
\hline Zakrzepica żylna & Brak danych & Obniżenie o 46\% \\
\hline $\begin{array}{l}\text { Główne punkty naczyniowe w zakresie } \\
\text { kończyn }\end{array}$ & Obniżenie o 35\% & \\
\hline
\end{tabular}

ASA (acetylsalicylic acid) — kwas acetylosalicylowy; NS — nieistotne statystycznie

klinicznych z lekami oddziaływującymi na PAR wydaje się potwierdzać, że leki pozbawione wpływu na PAR-2 działają mniej korzystnie. Przykładem może tu być worapaksar (antagonista PAR-1), którego zastosowanie skutkowało zmniejszeniem ryzyka konieczności rewaskularyzacji obwodowej u pacjentów z chorobą naczyń obwodowych, przy jednoczesnym wyższym ryzyku krwawień ze względu na dominującą dystrybucję PAR-1 na płytkach.

\section{RIWAROKSABAN Z ASA CZY TIKAGRELOR Z ASA W PREWENCJI WTÓRNEJ — KTÓRY PLEJOTROPIZM BARDZIEJ KORZYSTNY?}

Jeżeli faktycznie plejotropowe działanie małych dawek riwaroksabanu w połączeniu z ASA jest tak korzystne dla pacjentów z miażdżycą — nawet tych wiele lat po przebytym incydencie wieńcowym (model badania COMPASS [Cardiovascular Outcomes for People Using Anticoagulation Strategies]) - to porównajmy to z sytuacją stosowania u tych pacjentów uznanego plejotropowego leku (dodatkowe mechanizmy adenozynowe) - tikagreloru z ASA (model przedłużonego leczenia dwoma lekami po roku od incydentu wieńcowego - badanie PEGASUS [Prevention of Cardiovascular Events in Patients with Prior Heart Attack Using Ticagrelor Compared to Placebo on a Background of Aspirin]). Celem tego zestawienia jest nie tyle porównanie obu strategii (mimo wszystko nieco inne populacje pacjentów, z czego wynika trudność takiego rozumowania), ile dokonanie kilku istotnych, farmakologicznych konstatacji. Jeżeli riwaroksaban z ASA (model badania COMPASS) bylby co najmniej tak dobry jak tikagrelor z ASA (model badania PEGASUS), to można by to potraktować jako potwierdzenie plejotropowych działań riwaroksabanu, ponieważ plejotropizm tikagreloru jest już powszechnie zaakceptowany. Porównajmy zatem wybrane punkty końcowe obu badań (tab. 1).

Porównania takie jak powyżej zawsze wywołują protesty, bowiem, jak wspomniano, populacje porównywanych badań są różne, a siła statystyczna ze względu na różną liczbę punktów końcowych w konkretnych badaniach również się różni, co może powodować obecność lub brak istotności statystycznej dokonywanej obserwacji. Ale czy rzeczywiście? Porównajmy zatem jeszcze raz dane z badania PEGASUS z danymi z badania COMPASS i zastanówmy się nad zasadnością takiego zestawienia (tab. 2).

Wnioski z analizy obu tabel pozostawiam Czytelnikom. Wydaje mi się jednak ekscytujące, że mamy obecnie co najmniej dwa sposoby plejotropowego podejścia do chorych z miażdżycą, zwłaszcza tych z wywiadem ostrego zespołu wieńcowego (ACS, acute cardiac syndrome) kilka lat temu. Już za kilka miesięcy Europejskie Towarzystwo Kardiologiczne (ESC, European Society of Cardiology) ogłosi koniec epoki stabilnej choroby wieńcowej i wprowadzimy nową nomenklaturę tak zwanych przewlekłych zespołów wieńcowych (CCS, chronic cardiac syndromes). Już teraz należy się zastanawiać nad pozycjonowaniem zaproponowanych plejotropowych metod leczenia u takich właśnie pacjentów z CCS. 
Tabela 2. Porównanie wybranych aspektów badań PEGASUS i COMPASS wraz z siłą statystyczną badanych punktów końcowych. Porównanie zainspirowane wykładem prof. George'a Andrikopoulosa z Henry Dunant Hospital Center w Atenach, Grecja

\begin{tabular}{|c|c|c|}
\hline Porównywany aspekt badań & $\begin{array}{c}\text { Badanie PEGASUS } \\
\text { (tikagrelor } 60 \mathrm{mg}+\text { ASA) }\end{array}$ & $\begin{array}{c}\text { Badanie COMPASS } \\
\text { (riwaroksaban } \\
2 \times 2,5 \mathrm{mg}+\text { ASA) }\end{array}$ \\
\hline Liczba pacjentów & 21162 & 27395 \\
\hline Średni wiek włączonych do badania & 65 & 68 \\
\hline Odsetek kobiet (\%) & 24 & 22 \\
\hline Odsetek osób z GFR < 60 ml/min/1,73 m² (\%) & 24 & 23 \\
\hline Odsetek osób z chorobą wieńcową (\%) & 100 & 91 \\
\hline Średni czas po zawale serca (lata) & $1-3$ & 7 \\
\hline Odsetek osób z chorobą naczyń obwodowych (\%) & 5 & 27 \\
\hline Odsetek chorych na cukrzycę (\%) & 32 & 38 \\
\hline Odsetek osób z przebytym udarem mózgu (\%) & Wyłączeni z badania & 4 \\
\hline $\begin{array}{l}\text { Potrójnie złożony punkt końcowy (zgon, zawał serca, udar } \\
\text { mózgu) }\end{array}$ & 578 & 496 \\
\hline Zgon sercowo-naczyniowy & 210 & 203 \\
\hline Udar mózgu & 122 & 142 \\
\hline Zawał serca & 338 & 205 \\
\hline Zgony z dowolnej przyczyny & 326 & 378 \\
\hline \multicolumn{3}{|l|}{ Ocena jakości przeprowadzonego badania: } \\
\hline - odsetek osób, które przerwały badanie w okresie trwania (\%) & 28,7 (33 miesiące) & 16,5 (23 miesiące) \\
\hline $\begin{array}{l}\text { - kompletność obserwacji odległej wszystkich pacjentów } \\
\text { pierwotnie włączonych do badania w zakresie odsetka osób, } \\
\text { których przeżywalność zbadano (tzw. vital status) (\%) }\end{array}$ & 99,2 & 99,8 \\
\hline
\end{tabular}

ASA (acety/salicylic acid) — kwas acetylosalicylowy; GFR (glomerular filtration rate) — współczynnik filtracji kłębuszkowej w ml/min/1,73 m²

\section{KONFLIKT INTERESÓW}

Honoraria za wykłady, udział w sesjach satelitarnych i ciałach doradczych następujących firm produkujących leki przeciwkrzepliwe i przeciwpłytkowe: Adamed, AstraZeneca, Bayer, Boehringer Ingelheim, Pfizer, Polpharma, Sanofi.

\section{PIŚMIENNICTWO}

1. Barylski M, Mamcarz A, Siebert J, et al. Nowy paradygmat leczenia przeciwzakrzepowego chorób miażdżycowych. Stanowisko grupy ekspertów wsparte przez Sekcję Farmakoterapii Sercowo-Naczyniowej Polskiego Towarzystwa Kardiologicznego dotyczące miejsca riwaroksabanu w terapii stabilnej choroby wieńcowej lub objawowej choroby tętnic obwodowych. Choroby Serca i Naczyń. 2019; 16(1): 1-16, doi: 10.5603/ChSiN.2019.0002.

2. Witkowski A, Barylski M, Filipiak KJ, et al. Non-vitamin K antagonist oral anticoagulants (NOACs) in the treatment of coronary and peripheral atherosclerosis. Expert Consensus of the Association for Cardiovascular Interventions, Working Group on Intensive Cardiac Care and Resuscitation, and Working Group on Cardiovascular Pharmacotherapy of the Polish Cardiac Society. Kardiol Pol. 2019; doi: 10.5603/KP.a2019.0033. 